\title{
New Frontiers of Knowledge: Science and Technology in the Late 1950s American Cold War Propaganda
}

Trevor Rockwell, University of Alberta

Abstract

My essay assesses how science and technology were depicted in American Cold War propaganda and suggests these themes were vital to the US propaganda strategy of the late 1950s. Focusing on the United States Information Agency and its radio organ the Voice of America, I examine the significant role played by the VOA, tracing a shift towards the exploitation of science and technology themes in the late 1950s, and briefly analyzes the content of the 1957 science-themed VOA series "New Frontiers of Knowledge." Finally, some concluding remarks explore how science was used to advance the broad foreign policy strategy of the United States.

\section{Introduction}

During the 1950s, the superpower confrontation between the United States and the Soviet Union rarely played out on traditional battlefields. Propaganda--or in the terminology of the time, psychological warfare--played a central role in the Cold War. By the 1950s, as scholar Kenneth A. Osgood observed, "Psychological warfare had 
become, in essence, a synonym for cold war."1 So soon after Hiroshima and Nagasaki, the 1950s was also a decade of widespread anxiety about nuclear arms and awareness--if apprehension--of science and technology, most noticeably surrounding the October 1957 launch of the Soviet space satellite Sputnik during the International Geophysical Year.

The theme of science was increasingly important for American propaganda in the late 1950s, particularly after Sputnik so visibly challenged American scientific supremacy in 1957. The VOA's depiction of American science sought to make clear the superiority of the western system, and this depiction complemented the broader propaganda objectives of the US at the time. In particular, the series New Frontiers of Knowledge--an extended group of lectures on science and technology themes produced and broadcast by the American propaganda radio station Voice of America (VOA) in 1957--suggests that science was indeed vital to the overall US propaganda strategy in the 1950s. The VOA was an organ of the United States Information Agency (USIA), the US government's foreign propaganda agency. Its broadcasts were directed primarily at audiences within the USSR and Soviet Bloc.

This essay will examine the significant role that the VOA played within the overall American propaganda objectives in the late 1950s, and then demonstrate the importance of science and technology themes for American propaganda of the late 1950s. Finally, it will briefly analyze the content of the New Frontiers of Knowledge series to

${ }^{1}$ Kenneth A. Osgood, "Hearts and Minds: The Unconventional Cold War," Journal of Cold War Studies, 4. 2 (Spring 2002): 85-86. 
assess how science and technology were depicted in American propaganda and offer some concluding remarks exploring how science and technology were used to advance the broad foreign policy strategy of the United States. This essay argues throughout that American Cold War propaganda employed a politically charged discourse on science and technology, one far removed from the supposed neutrality of science.

\section{The significance of the VOA in the late 1950s}

International propaganda took on an increasingly significant role in the conduct of American foreign policy during the 1950s, and radio propaganda was at the center of US propaganda strategy. As Osgood observed, "American policy makers increasingly realized that the Cold War would be won or lost on the plane of public opinion, rather than by blood shed on the battlefield". ${ }^{2}$ Right from the decade's outset, President Truman's 1950 anti-communist "Campaign of Truth" substantially increased appropriations for international information programs. By 1951 American government investment in overseas propaganda more than quadrupled the amount spent in $1949 .^{3}$

\footnotetext{
2 Kenneth A. Osgood, "Hearts and Minds," 86.

${ }^{3}$ Alan L. Heil Jr., Voice of America: A History (New York: Columbia University Press, 2003), 49; Ronald I. Rubin, The Objectives of the U.S. Information Agency: Controversies and Analysis (New York: Praeger, 1968), 113; Dick Fitzpatrick, "America's Campaign of Truth throughout the World," in Journalism Quarterly (Winter 1951); Roland I. Peruse, "Psychological Warfare Reappraised," 29; Kenneth A. Osgood, "Hearts and Minds," 97; US Senate, Overseas Information Programs of the United States, Report 406, 83rd Congress, 1st Section, p. 48; Anthony Leviero, "Organization, Mission and Operation of the Psychological 
A series of government offices overseeing international propaganda operations--including the VOA-culminated in a centralized agency with the creation of the USIA in 1953. ${ }^{4}$ The new Agency was a product of promises Eisenhower made in the previous years' campaign for the White House. Eisenhower's great faith in the power of overseas propaganda and what he called the "psychological factor" of national security, borne of his WWII experience when he personally supervised the Allied propaganda broadcaster Radio 1212. Concerns over American international prestige made overseas information programs an election issue during the 1952 Presidential campaign, and Eisenhower promised to strengthen these operations if voted in. After his election Eisenhower continued to support the expansion of American overseas propaganda. The Soviet launch of Sputnik in 1957 only hardened Eisenhower's conviction that the "psychological factor" - especially the "attitude" of American allies - was of tremendous importance to US national security. As he told a closed meeting of his advisors on February 6, 1958, to stress the importance of psychological considerations, "at times appearances are as significant as the reality, if not more so."5

Strategy Board and Related US Agencies" (six consecutive articles), in The New York Times, 10-15 Dec 1951

${ }^{4}$ Ronald I. Rubin, The Objectives of the U.S. Information Agency, 110; George V. Allen, "The People-To-People Program: Let Facts be Submitted to a Candid World," Vital Speeches of the Day 24.10 (3 January 1958): 292-295; Alan L. Heil Jr., Voice of America: A History. 53-55.

5 Walter L. Hixson, Parting the Curtain: Propaganda, Culture and the Cold War (New York: St. Martin's Press, 1997), 59; Memorandum of Conference with the President: February 4, 1958 (following Legislative Leaders meeting), 2, 4; Ronald I. Rubin, The Objectives of the U.S. Information Agency, 118, 120. 
Eisenhower personally submitted to Congress on June 1, 1953 a document called Reorganization Plan No. 8 that proposed the establishment of the USIA. Subsequent Congressional approval led to the USIA's formal inauguration on August 1, 1953. ${ }^{6}$ Funding for the USIA increased substantially, if not steadily, over the first decade of the Agency's existence from $\$ 84.2$ million in 1954 to $\$ 159.9$ million in 1965 . The most significant jump in USIA resources came in fiscal year 1957 when total appropriations jumped to $\$ 113$ million from $\$ 87.3$ million in 1956. Most of these funds went towards the mass media programs - the radio, press and motion pictures in an attempt to reach the masses with information campaigns that had up to this point limited their focus to foreign elites. $^{7}$

The USIA's Radio Division was the Voice of America. While the USIA was officially given, "complete responsibility for all United States non-military overseas information programs", unofficially the CIA organized and sponsored its own stations, which they falsely claimed were being operated and funded by a "private sector" organization called the Committee for Cultural Freedom. ${ }^{8}$ The emergence of these stations began with Radio Free

${ }^{6}$ Ronald I. Rubin, The Objectives of the U.S. Information Agency, 119, 127; Alan L. Heil Jr., Voice of America: A History. 56.

7 Ronald I. Rubin, The Objectives of the U.S. Information Agency, 51, 113.

8 John Scott, "Non-Governmental Agencies Engaged in Cold War Propaganda Operations." In A Psychological Warfare Casebook, 154; Walter L. Hixson, Parting the Curtain, 59-65; Arch Puddington, Broadcasting Freedom: The Cold War Triumph of Radio Free Europe and Radio Liberty. (Lexington, KY: University Press of Kentucky, 2000), 22; Kenneth A. Osgood, "Hearts and Minds," 93; King, Gene. "A New Kind of Diplomacy." The Quarterly of Film Radio and Television 10.1 (Autumn 1955), 50. 
Europe (RFE), in December 1949 and continued throughout the 1950s with Radio Free Asia (RFA), and Radio Liberation, which later became Radio Liberty (RL). The emergence of these new propaganda radio stations in the 1950s reflected the increasing importance of radio propaganda, and highlighted the significance of the VOA's "educational" style of broadcasting. ${ }^{9}$ The 1956 uprisings in Poland and Hungary suggested to many that American radio propaganda was effectual. Washington also became more resolved that the VOA take a cautionary approach and closely follow the government's official position. ${ }^{10}$

Instructed to take an evolutionary rather than revolutionary approach, the VOA became even more restricted from the "hard-hitting psychological warfare", that the other stations were free to support. As an official government broadcaster, the VOA was obliged to certain "diplomatic niceties" that the other American broadcasters were not. Educational and cultural programming became more important, while VOA content was made to more closely reflect how the American government wished to portray itself. ${ }^{11}$

The VOA began broadcasting on February 25, 1942-just 79 days after Pearl Harbor--to support the Allied effort in World War Two. From the very beginning VOA was a multilingual service especially aimed at enemy combatants. By the summer of 1944 the wartime VOA

\footnotetext{
9 John Scott, “Non-Governmental Agencies, 153.

10 Ronald I. Rubin, The Objectives of the U.S. Information Agency, 128.

11 John Scott, "Non-Governmental Agencies, 153; Arch Puddington,

Broadcasting Freedom, 43; Kenneth A. Osgood, "Hearts and Minds," 92; Walter

L. Hixson, Parting the Curtain, 59, 83.

Past Imperfect 
reached its apex broadcasting in over forty languages plus an additional ten different dialects for the Philippines and over 3,000 staff worldwide. After WWII, the Voice was briefly demobilized as part of the broad "virtual psychological disarmament of the US". In 1946 the VOA's staff was cut by two thirds and the total languages dropped to twenty-three. Tensions with the Soviet Union that year, however, prompted the US to establish a peacetime international radio service. The VOA launched a special Russian Service on February 17, 1947 and over the course of the 1950s it became the "chief technique for penetrating the Curtains." 12 Although Africa, Asia, and Latin America became increasingly targeted with USIA propaganda after the mid-1950s, a large ratio of American radio transmissions were still directed at Eastern Europe. By 1955, about seventy-five percent of VOA broadcasts and about five-eighths of its $\$ 16$ million budget, was being channeled into programs directed into the "Communist orbit". That year the VOA transmitted about 76.5 hours of programming into the USSR and Soviet Bloc each day. ${ }^{13}$

Radio became the USIA's medium of choice as the Agency realized the drawbacks associated with other propaganda methods. Soviet anti-aircraft guns shot down

\footnotetext{
12 Alan L. Heil Jr., Voice of America: A History. 32-44; King, Gene. "A New Kind of Diplomacy." The Quarterly of Film Radio and Television 10.1 (Autumn 1955), 45; Roland I. Peruse, "Psychological Warfare Reappraised," 29; Alan L. Heil Jr., Voice of America: A History. 46.

${ }^{13}$ Heil, Voice of America, 49-50; Walter L. Hixson, Parting the Curtain, 30; United States, National Security Council. "Status of National Security Programs," 1-26; Kenneth A. Osgood, "Hearts and Minds," 99: King, Gene. "A New Kind of Diplomacy." The Quarterly of Film Radio and Television 10.1 (Autumn 1955), 4546.
} 
leaflet balloons and authorities persecuted those who collected, read and distributed leaflets and pamphlets with increasing vigor. One such campaign conducted by the Free Europe Committee (FEC) was discontinued in October 1956 after distributing around 300 million propaganda articles via over 600,000 balloons. The families of students who enrolled for an anti-communist education at the Free Europe University in Strasbourg France - the largest group of whom were from Berlin's Russian zone - were harassed and the students themselves often faced arrest when they returned home for visits. The material nature of these types of propaganda made it easier for foreign authorities to apprehend and arrest the intended audience of American propaganda. Radio waves provided an attractive and economical way to disseminate information, as it was more difficult to stop radio waves, and keep track of who was listening in to them. Radio not only bridged distances it also left a much smaller footprint, making it much more difficult for states to monitor and control the material, and allowing propagandists to reach directly into people's homes. ${ }^{14}$

In January 1958, George V. Allen, then Director of the USIA, outlined his outlook on the relative success of the first year of an international exchange program called the People-to-People movement launched in 1956. ${ }^{15}$. Here he essentially echoed the views of the New Frontiers of Knowledge series, particularly in regards to the effect that

14 Walter L. Hixson, Parting the Curtain, 65-67.

15 Ronald I. Rubin, The Objectives of the U.S. Information Agency, 128. For an overview of the first two years of the People-to-People Program written by the director of the USIA, George V. Allen, see: George V. Allen, "The People-ToPeople Program," 292-295. 
science and technology had on international relations. "The growth of industrialization is one reason," he explained, "for the increasing development of international independence." Noting that there was comfort to be drawn in the fact that nations were not facing the nuclear threat alone, he continued:

The foreign policies of the United States today recognize both these factors. The chief cohesive forces, as I see it, are the democratic principles to which we are committed and which we seek to preserve. To the USIA has been assigned the job of publicizing these policies abroad and interpreting them for other peoples. ${ }^{16}$

These comments reflect the place of science within Allen's conception of the international role of the USIA. In a world made smaller by technological improvements to communications and transportation, the technical demands of industry and the power of science to threaten the very existence of humankind had raised the significance of publicizing "democratic principles". The connections that Allen made here - associating the United States with science, technology, and democratic traditions, while emphasizing that American leadership is the answer to avoiding the apocalypse of nuclear war - are echoed in the selection of lectures that comprised the New Frontiers of Knowledge program.

16 George V. Allen, “The People-To-People Program,” 293.

Past Imperfect 


\section{Science and American propaganda}

Political events in Eastern Europe in 1956 revealed to Americans the meaningful and effectual role that radio propaganda could play in current events. After Soviet Premier Nikita Khrushchev delivered his so-called Secret Speech denouncing Josef Stalin to a closed session of the Twentieth Congress of the Communist Party of the Soviet Union on the night of February 24-25, 1956, the CIA intercepted the text of the speech. On June 4, the New York Times published the speech and American propaganda radio stations began widely discussing it on the air. In this way the VOA, Radio Free Europe and Radio Liberty contributed to the political crisis that emerged in the summer and fall of 1956 in Eastern Europe. It was felt that American propaganda had encouraged the uprising and thus contributed to the harshness of the Soviet crackdown on the dissidents. The US soon instigated a review of the American radio stations activities during the Hungarian crisis. While controversy swelled around the CIA's RFE and $\mathrm{RL}$, the Voice was found to have "neither encouraged or discouraged the Hungarian freedom fighters". After 1956, the VOA found its credibility considerably enhanced due to its less confrontational style of straightforward reporting and focusing on cultural and educational programming. ${ }^{17}$

These events also enhanced the importance of science for American propaganda. In the aftermath of the Hungarian uprising, American propaganda activities

17 Walter L. Hixson, Parting the Curtain: Propaganda, Culture and the Cold War, 78-83.

Past Imperfect 
concentrated on "creative--if gradualist--approaches to the ultimate goal of breaching the Iron Curtain" designed to nurture a "pro-Western outlook" among Soviet citizens. The persuasive approach of the USIA and the VOA thus became more preferable than the aggressive approach taken by the CIA-sponsored stations Radio Free Europe and Radio Liberty, because the VOA was a less provocative and safer choice for keeping the Cold War from heating to the point of full-blown conflict. New guidelines issued by Eisenhower himself on June 3, 1957 and designed to "eliminate the 'propaganda' tone" altogether brought the VOA under even tighter supervision. The limitations forced on the VOA as an official organ of the United States government also make it an excellent case study for examining how the official American position was expressed within a forum of international radio propaganda. ${ }^{18}$

A 1958 USIA report to the NSC indicated that one of the "most important developments" of 1957 had been the clarification of the VOA's distinct approach, which represented a move towards a gradualist long-range approach to effecting change, and to tailoring messages towards reaching elite intellectuals among foreign audiences. ${ }^{19}$ The overall propaganda objectives did not change at this time as much as the tone, style, and tactics employed. ${ }^{20}$ The shift in strategy from 'revolutionary' to 'evolutionary' approaches thus did not constitute a retreat

18 Ibid., 83, 86.

19 United States, National Security Council. "Status of National Security

Programs on June 30, 1958," 14, 7.

20 Kenneth A. Osgood, "Hearts and Minds," 98. 
from the psychological battlefield. Radio, which "remained the most effective medium" for the USIA propaganda effort, reported an "overall increase in U.S. information and cultural activity behind the Iron Curtain" during fiscal year 1958. ${ }^{21}$ The evolutionary approach reflected the increasing sophistication of American propaganda.

Thus, while the USIA momentum shifted towards producing more "educational" programs and less obvious outright propaganda, the aftermath of Hungary, the International Geophysical Year, and then Sputnik, all combined to increase the importance of science and technology themes for USIA propaganda during the late 1950s. Scientific programming such as the New Frontiers of Knowledge series became central to American Cold War propaganda by 1957. "More and more it was becoming evident that the Agency's most important task," the 1958 USIA report argued, "was to publicize America's spectacular advances in medicine, science, and technology." The first "Major Informational Problem" discussed in the report focused on "The Technological Race". The report noted: "All Agency media gave special emphasis to science information--space experiments, atoms-for-peace and rocket missiles". Additionally, USIA news staff expanded to include a writer specifically dedicated to strengthening, "coverage of science news, especially IGY activities." A "University of the Air" program scheduled to air in late 1958 would further strengthen the Agency's focus on themes of science and technology by hosting lectures by

21 United States, National Security Council. "Status of National Security Programs," 14. 
American academics in "the natural sciences, the social sciences, and the humanities."22

As the report unequivocally stated, "The psychological position of the United States was seriously challenged during the year which ended June 30, 1958." But Sputnik was "far from being the most disturbing" of Soviet efforts to "damage foreign respect for American scientific ability and military strength". Soviet propaganda projecting themes of peace, progress, and Soviet strength, was, according to the report, "more subtle and difficult to cope with." Another significant aspect of the USIA propaganda had been to respond to the post-Sputnik criticism of the American education system, largely by denying the basis for any such claims. Of special concern to the USIA public opinion analysts was how studies showed Western Europeans were becoming less willing to "accept American statements at face value."23

A September 1958 National Security Council report-NSC 5819--outlined the key strategies for the USIA's effort in Western Europe, and stressed the need for science and technology themed propaganda. NSC 5819 called for a "heavy increase in output designed to show the underlying and fast-developing strength of American science [...] the continued leadership of the free world in most fields of technology and the essentially humanistic nature of free world science." The second point further emphasized that Western "scientific cooperation" was essential for the

22 Ibid., 3-4, 8-9.

23 Ibid., 2. 
"vitality and prosperity--as well as the security--of the West". ${ }^{24}$

In fact, an emphasis on science and technology was already underway, and had been spurred forward by the launch of Sputnik. The satellite had not been in orbit for more than twenty-four hours before the USIA embarked on a global scale propaganda counter-offensive. In Rio de Janeiro, the Agency brought the leading Brazilian missile scientist onto television "to allay fears of Soviet missile supremacy." USIA posts swiftly organized displays, often in the downtown cores of large cities, of American satellite plans. The USIA did not attempt to "minimize" the significance of Sputnik, but stressed Eisenhower's line that the US was "not in a race" but was following a schedule more determined by the United States' contributions to the International Geophysical Year. Still, the USIA found it necessary "to allay the trepidations of allies" by reminding them of American progress in producing nuclear capable missiles and rockets. ${ }^{25}$

A "major task" for the Film Service in the wake of Sputnik was "offsetting the impression of Soviet scientific superiority". Without a successful U.S. satellite to publicize, the USIA film service quickly produced the documentary film Defensive Sky Power, which showcased "the impressive array of missiles developed by the U.S. as a major contribution to the security and freedom of the free world." After the successful launch of Explorer I, the USIA film The Explorer in Space stressed the satellite's "scientific

24 Ibid.,16.

25 Ibid., 4, 26. 
character" and its contribution to the IGY. A similar film on Vanguard I came in March. ${ }^{26}$

While the USIA expanded its fleet of overseas Information Centers throughout the late 1950s, exhibits at these posts shifted their focus towards science and technology themes, highlighting the American space effort, IGY contributions, and peaceful use of nuclear energy. Three new Information Centers were opened in Africa in FY 1958 , bringing the total to 156 , while eight more were planned for the next year. In support of this effort, the Agency shipped to its posts 120 scale models of the Explorer and Vanguard satellites, accompanied by other display materials. Twenty-one countries thus featured the USIA's "Space Unlimited" exhibit that year. Meanwhile the USIA continued to ship "Atoms-for-Peace" exhibits that year and all foreign posts received a model of a planned IGY exhibit with a special focus on the US. As the year-end report to the National Security Council stated, these exhibits were designed, "In support of NSC overall objectives". ${ }^{27}$

Perhaps no greater evidence of the significance of science and technology themes for American radio propaganda during the 1950s exists than the analysis of VOA content completed in 1959 by two members of the Propaganda Department of the Central Committee of the Communist Party of the Soviet Union. Their report classified VOA (and BBC) propaganda into falling under seven basic headings, one of which was: "Stress on

${ }^{26}$ Ibid., 10.

27 Ibid., 11-12. 
American technical progress, especially in the use of nuclear energy, and on the desire of the United States and Great Britain for international collaboration by scientists."28

The New Frontiers of Knowledge series reflected another 1950s trend towards the increasingly scientific study of the mass media and its influence on attitudes, opinions and behaviors. The USIA was vitally important to the growing appreciation for data gathered from public opinion surveys during the period. International surveys of media habits and attitudes towards American foreign policy had been conducted since 1945. At first this was handled by the Department of State, but since the founding of the USIA in 1953 this had become mainly the Agency's jurisdiction. According to Elmo C. Wilson who published a concise overview of the international emergence of public opinion surveys in The Public Opinion Quarterly, by 1957 the United States was a global leader in this type of research. That year, the USIA conducted polls to deduce, among other things, the impact that the launch of Sputnik had on public opinion. The study revealed that many outside the US felt that the US had fallen behind the Soviets in technological development. ${ }^{29}$

The USIA also collaborated with the scientific community to in order to take a more scientific approach to propaganda and to the organization of the Agency itself. In

28 Michael Nelson, War of the Black Heavens: The Battles of Western Broadcasting in the Cold War (Syracuse: Syracuse University Press, 1997), 97. 29 Elmo C. Wilson, "World-Wide Development of Opinion Research," in The Public Opinion Quarterly 21.1 (Spring 1957), 177; Michael Nelson, War of the Black Heavens, 101. 
1953, a "distinguished Advisory Committee of social scientists" proposed to the Director of the USIA to undertake an extended study into "working assumptions" and the theoretical foundations behind the Agency's operations. The study conducted intensive interviews, between two and eight hours long each, with high-level USIA personnel. The final report from this research filled 900 pages and five volumes. One of the report's findings showed how the USIA was principally concerned with the same problems as "such fields of social science as history, political sociology, social geography, cultural anthropology, the study of social movements, social organization, and comparative government." 30 According to the report, the USIA and the social sciences had much to offer each other. It is difficult to measure the effect of the report on the dayto-day workings of the USIA, but simple agreement to partake in such research indicated a willingness to submit the operation of the Agency to scientific scrutiny.

The study also reflected how social scientists in the 1950s were becoming more interested in propaganda, communications, and media studies. The decade witnessed the emergence of widespread interest in the theory and psychology of advertising. This was reflected in new terminology such as "planned obsolescence" and "gimmick" that came into use at the time. Popular awareness of this evolving field of study was reflected in the high sales of Vance Packard's The Hidden Persuaders, which was

\footnotetext{
30 Leo Bogart, "A Study of the Operating Assumptions of the U.S. Information Agency," ThePublic Opinion Quarterly 19.4 (Winter 1955-1956), 369-379. 
published in 1957 and went on to become a million-seller. ${ }^{31}$ More significantly, presidential elections began to exploit the talents of professional advertising men in 1952 and the television industry in $1956 . .^{32}$ The success of such experts as the "'father' of Motivational Research", Dr. Ernest Dichter attests to how the credibility of the advertising industry was rapidly growing at the same time as it was becoming increasingly scientific. ${ }^{33}$ In the 1950 s, advertising thus became more scientific, more credible, and more widely deemed to have significant power and value. The increasing respect for advertising further enhanced the value of propaganda as a foreign policy tool.

As with advertising, the 1950s also saw the field of communications and media studies more and more claiming identification as a science. Writing in 1956, Harry Alpert explored comparisons between public opinion research and "other scientific disciplines" in the pages of The Public Opinion Quarterly. ${ }^{34}$ Indeed, this journal itself reflected an increase in public opinion surveys and the systematic study of the effects of mass media and communications since its founding in $1937 .{ }^{35}$ In 1957, a special issue celebrated the great strides made in public opinion research in the previous two decades. Harold

31 Vance Packard, The Hidden Persuaders, (New York: Pocket Books, 1957).

32 Thomas P. Doherty, Cold War, Cool Medium: Television, McCarthyism, and American Culture (New York: Columbia University Press, 2003).

33 Peter Lewis, The Fifties, 18-19, 25-26.

34 Harry Alpert, "Public Opinion Research as Science," The Public Opinion Quarterly 20.3 (Fall 1956), 493-500.

35 For an overview of contemporary currents in the field see in particular: Bruce Lannes Smith, "Trends in Research on International Communication and Opinion, 1945-55." The Public Opinion Quarterly 20.1, Special Issue on Studies in Political Communication (Spring 1956), 182-195. 
Lasswell wrote a compelling article for this issue in which he showed the profound impact that the tools of public opinion research had begun to make on society, while he and others--including Paul Lazarsfeld--raised some interesting theoretical questions in regard to this development. 36

In the fifties, the USIA also maintained a close working relationship with the American Association for the Advancement of Science (AAAS). The two organizations had many common objectives; both were deeply concerned with national security and with the advancement of science. In 1954 and in 1957, the AAAS drafted and passed two important resolutions on national security. While these resolutions sought to establish the limits of government influence on the scientific community, they also fundamentally affirmed the loyalty of the AAAS to the American government and the Association's commitment to work towards a "positive program" of national security. As the 1954 Resolution stated, "Disloyalty is not to be tolerated anywhere."37

The journal Science, affiliated with the AAAS since 1900, often carried announcements about USIA activities such as the announcement in the December 1955 issue

\footnotetext{
36 Harold D. Lasswell, "The Impact of Public Opinion Research On Our Society." The Public Opinion Quarterly 21.1, Anniversary Issue Devoted to Twenty Years of Public Opinion Research (Spring 1957), 33-38; Paul F. Lazarsfeld, "Public Opinion and the Classical Tradition." The Public Opinion Quarterly 21.1, Anniversary Issue Devoted to Twenty Years of Public Opinion Research (Spring 1957), 39-53.

37 The Board of Directors of the American Association for the Advancement of Science, "AAAS Resolution: Strengthening the Basis of National Security," in Science, 120, December 10, 1954.
} 
that: “The U.S. Information Agency's pamphlet Atomic Power for Peace has been printed in 35 languages for a total of almost 6 1/2 million copies since May 1954."38 The journal also sometimes solicited assistance for the USIA from the American scientific community. In December 1956 for example, the back pages of Science made a request for colleges and universities to donate 200 copies of their course catalogues for distribution at USIA posts overseas in order "to acquaint people in other countries with the facilities of American higher education. "39

Science also reported on groups such as the Society for the Investigation of Human Ecology, which met on April 12, 1957 to discuss the "Human Ecology of the Hungarian Episode". At this meeting, representatives of various universities, the National Academy of Sciences and the National Science Foundation, the USIA and RFE shared information and insights on the 1956 Hungarian uprising. 40 The pages of this journal thus provide another outlet for assessing the USIA's activities in the realm of disseminating information about science to the public both domestically and abroad. ${ }^{41}$ The close working relationship between the USIA and the AAAS further underlined that science was an essential aspect of American propaganda in the 1950s.

Significantly, many of the ideas articulated in the New Frontiers of Knowledge series were ideas that had

38 "Miscellaneous," in Science, New Series, 122: 3183, (Dec. 30, 1955): 1265. 39 "USIA University Catalog Program," in Science, New Series, 124: 3234, (Dec. 21, 1956), 1246.

40 "Meetings and Societies: Human Ecology and the Hungarian Episode," in Science, New Series, 125: 3261, (Jun. 28, 1957), 1306.

41 "News Briefs: “Overseas library," in Science 131:3396 (29 January 1960): 291. 
been already expressed by the AAAS. Articles in Science, and meetings of the AAAS stressed the importance of scientific education and communicating the work and discoveries of the scientific community to the masses. Often commentators revealed their belief that the international spread of scientific education could possibly bring material, social and political progress to underdeveloped regions. The Association's 1954 Resolution drew strong connections between the "knowledge, talent, and enthusiasm," and, "fundamental loyalty of American scientists, engineers, and industrialists" which would not only, "keep the United States ahead of potential enemies," but also, "strengthen the democratic spirit of freedom and of progress which is the hope of the free world." 42 These same relationships between the benefits of science and the social and political traditions of the United States were repeatedly emphasized in the New Frontiers of Knowledge series.

Catalogs of USIA propaganda materials from the late 1950s also suggest the primary importance of science within the USIA's outlook. Beginning in 1956, the USIA compiled three book-length reports for a catalog of documentary films to be distributed by the Agency. The first of these catalogs was devoted entirely to the "Science Section", with the second and third catalogs focusing on the "Education Section" and the "Cultural Section" respectively. Compiling this catalog was part of a larger project taking place since 1952 that had by 1959 already listed

42 The Board of Directors of the American Association for the Advancement of Science. "Strengthening the Basis of National Security." Science, New Series, 120:3128 (10 December 1954), 959. 
approximately ten thousand films and identified more than thirteen thousand others from over five hundred sources. A quick survey of the subject headings within the "Education" catalog reveals that science and technology were of primary importance to the USIA's vision of education as well. For instance, of the seventeen subsections that the catalog classified, films under sections such as Transportation, Engineering, Communications, Agriculture, Aircraft and Vehicle Operation and Industrial Skills all suggested significant scientific or technological components. ${ }^{43}$

New frontiers of knowledge

New Frontiers of Knowledge offers one particularly rich source for examining how science and technology themes were exploited in American Cold War propaganda. The USIA published transcripts of these lectures in book form in 1957.44 Since published samples of programming content for the VOA are relatively scarce, the mere availability of this text underlines the significance ascribed to science and technology issues in the late 1950s. One other example of published VOA programming content from the period also focused on science. This, a weekly halfhour lecture series called "Forum-The Arts and Sciences in Mid-Century America," began broadcasting on January 5, 1959, and sought to cover "all the major fields of

43 United States Information Agency, United States educational, scientific, and cultural motion pictures and filmstrips: education section 1958, selected and available for use abroad, (Washington: United States Information Agency, 1959), iv-v, $x-x i$.

44 United States Information Agency, New Frontiers of Knowledge: A Symposium by Distinguished Writers, Notable Scholars \& Public Figures. (Washington, D.C.: Public Affairs Press, 1957). 
knowledge or cultural activity in which the United States may be considered pre-eminent". Many titles of this series are widely available under the title: "The Voice of America: Forum Lectures". ${ }^{45}$ As USIA broadcasts and publications, both of these works supported the Agency's purpose to fulfill a specific mandate of "strategic principles" which stated that:

We are in competition with Soviet Communism primarily for the opinion of the free world. We are (especially) concerned with the uncommitted, the wavering, the confused, the apathetic, or the doubtful within the free world. 46

The New Frontiers of Knowledge series was one of the centerpieces to the Agency's approach to fulfill this mandate, and an indication of the value of science and technology for American propaganda in the late 1950s. One of the most carefully planned examples of American government radio programming in the mid-1950s, as the title of the symposium suggests, the overarching theme is science. Even those speakers who are not strictly scientists per se often address the social and philosophical implications of scientific and technological advancements.

45 For a description of the program from before it actually hit the air, see: Walter Nichols, "Voice of America Forum Series." College Art Journal 19.3 (Spring 1960), 253.

46 Kenneth A. Osgood, "Hearts and Minds," 99. 
Looking at the demographics of the lecturers, the first thing one notices is that only two of the thirty-six speakers were women. The largest contingent, nearly half of those present, was the group of seventeen Americans. There were two each from Britain, Australia, Japan and Turkey; and one each from France, Spain, Switzerland, Norway, Lebanon, Ecuador, Brazil, India, Pakistan, and the Philippine Republic. Nearly every of the countries represented by the Frontiers of Knowledge speakers had a sizable USIA post operating on their soil. ${ }^{47}$ In terms of occupation, roughly one third were government figures; another third were scientists--including three Nobel Laureates--and academics; and the remaining third were authors, business leaders, and two Generals.

The Frontiers of Knowledge notably included lectures by Margaret Mead, the anthropologist known for her theory that Russians are predisposed to totalitarianism because of the way they are swaddled as children; Arnold Toynbee, the British historian famous for a general theory of history and civilization articulated in his twelve-volume A Study of History; Carl Jung, the founder of Analytical Psychiatry and originator of the theory of collective unconscious; and Sidney Hook, the founder and a leading member of the covertly CIA-funded propaganda organization the Congress for Cultural Freedom.

Prominent scientists included the American physicist Percy W. Bridgman, winner of the Nobel Prize in Physics in 1946 for his development of a useful apparatus

47 Kenneth A. Osgood, "Hearts and Minds," 100. 
for conducting high-pressure physics experiments; the Japanese theoretical physicist Hideki Yukawa who received the same honor in 1949 for predicting the existence of mesons; Hermann J. Muller the American geneticist who won the Nobel Prize in Medicine in 1946 for his discovery of gene mutation through $x$-ray radiation; and the Australian biologist Sir Frank MacFarlane Burnet who would later in 1960 also share the Nobel Prize in Medicine for his work in immunology.

Notable media figures included Walt Disney, the utopian, animator, businessman, and in this setting a propaganda theorist; Nelson Rockefeller, the grandson of oil-tycoon John D. Rockefeller, and the "grandfather of VOA" because since 1940 he had been the Coordinator of InterAmerican Affairs overseeing the first overseas broadcasts produced by the US (to Central and South America); David Sarnoff a pioneer in the American broadcast industry and then Chairman of the Board at RCA; Lee de Forest, the "Father of electronics" whose invention of the vacuum tube in 1906 led to the development of radio broadcasting, radar and television; and Henry Luce, the successful publisher and editor who created Time Inc. which published Time, Life, Fortune, and Sports Illustrated magazines.

Henry Luce's lecture titled "The World Americans Want" provides an excellent framework within which to summarize the main themes of the New Frontiers of Knowledge series. Luce and the other speakers in the series portrayed the United States as the ideal scientific society where faith and science had found a balance, in stark contrast with officially atheist Communist society. 
According to Luce, freedom of religion was the first and most important mark of the world that Americans want. "All the other points follow from this," he said, "because we want the kind of world God wants us to want." 48 The emphatic presence of this theme within a "scientific" series supports scholar Tony Shaw's observation that, "the persecution of religion under 'godless Communism' became one of the most emotive of the major themes of Cold War discourse in Western Europe and the United States". As Shaw has argued, the increasing political role of religious groups in the US had given many in Washington a "missionary mentality" and a sense that religious faith in Central and Eastern Europe was a great "spiritual resource" that could be "mobilized". ${ }^{99}$ The theme was also perhaps especially "emotive" within this late-1950s context, when state-sponsored Anti-Religious Campaigns were intensifying in the Soviet Union.

Many, maybe half of the speakers in the VOA series mentioned or discussed "God". Most importantly, the series did not hold science and faith to be in opposition to each other. Here, the idea was portrayed that science did not challenge or undermine God, but simply revealed God's work. As then President of Harvard University remarked in his lecture for the series, "We have always needed the mind of man, that wonderful and mysterious God-given mechanism." As the Pakistani and Moslem statesman

48 United States Information Agency, New Frontiers of Knowledge, 45.

49 Tony Shaw, "Martyrs, Miracles, and Martians: Religion and Cold War Cinematic Propaganda in the 1950s," Journal of Cold War Studies 4.2 (Spring 2002): 7. 
Zafrullah Khan stated, God is "the True Source of all knowledge and beneficence." 50 The series most ardently supported the notion that a scientific society requires an intellectual environment of freedom, and this includes religious freedoms.

Peace was the second most important feature of the world that, according to Henry Luce, Americans wanted. To nearly ever speaker science and technology can help prevent war, which is presented as the foremost problem facing humankind. It is largely claimed throughout the series that peace is the ultimate byproduct of a not only scientific, but also democratic society. In this way it is repeatedly implied, and sometimes explicitly stated that the scientific development of the Communist societies represents the chief threat to international peace and stability.

The third aspect of Luce's ideal was a "world in which all men are free to seek the truth--the scientific truth, the scholarly truth, the philosophic truth--and to utter truth as they see it." Sidney Hook, when he suggested that scientists had taken over the philosopher's traditional role, echoed this idea that the impact of science extended beyond the bounds within which it had been heretofore perceived. "For it is the scientist," Hook declared, "most broadly conceived, who gives us reliable knowledge about the nature of nature, the nature of society, and the nature of man." French author Jules Romains suggested that scientific thinking preserved "the freedom of the mind." More

50 United States Information Agency, New Frontiers of Knowledge, 38, 87. 
specifically, "scientific" thinking was defined as both the basis and product of Western--and American--social and political traditions. General Carlos P. Romulo considered it "the serious concern of free men everywhere to tear down the iron curtain that keeps so many millions ignorant or misinformed." ${ }^{51}$ Romulo emphasized the significance of information, suggesting that improvements in communication technologies, such as radio, could promote scientific thinking across the divide.

Luce's fourth ideal a "world of economic abundance" was also frequently associated with Western societies. The most significant theme expressed in the series is the idea that the global spread of science and technology will ultimately lead to prosperity from which international peace would inevitably follow. As Charles Malik expressed in the lecture that opens the book: "There is every reason to believe that science and technology... can solve every material problem facing mankind." 52 An implication ran throughout the series that Communist economic system was less capable than the capitalist system of providing the abundance that science promised.

As a fifth and final point, Henry Luce declared that Americans want "a democratic world". Some speakers equated American democracy with the same scientific traditions that promised the world prosperity and peace. Percy Bridgman, for instance, argued that Isaac Newton's ideas had, "inspired philosophical reactions which went as far afield as to mold the political philosophy of the

51 United States Information Agency, New Frontiers of Knowledge, 18, 26, 44-47. 52 Ibid., 4, 46. 
American founding fathers". 53 The series, in essence, claimed science as a Western and specifically American tradition. Tony Shaw has recognized this tendency in Cold War propaganda to "discursively associate" concepts into separate ideological packages. A fusion of religion, liberty, democracy, and Western civilization on one hand was contrasted with atheism, totalitarianism and Communism on the other. ${ }^{54}$

President Dwight Eisenhower associated the "new frontiers" of science with the frontier vision of America. "The history of America," Eisenhower wrote, "is a history of frontiers--each frontier a challenge."55 The series offered a characterization of the "new frontier" very much a product of the Cold War context from which it emerged, and for which it was meant to serve as propaganda. Taken as a whole, the lectures exhibit a tension between the sense that the world is on the verge of either final war or everlasting global peace. Another closely related theme running through the series suggests that the global spread of science and technology will lessen the power of political institutions based on geography and nationality. John von Neumann, for example, called the "intrinsic conflict with geography and institutions based thereon [...] the maturing crisis of technology." Perhaps predictably, the speakers repeatedly use this argument to predict that the regional or national institution most destined to dissolve is the Soviet Union. As General Carlos P. Romulo explained, the nuclear

53 Ibid., 13, 46.

54 Tony Shaw, "Martyrs, Miracles, and Martians," 7.

55 United States Information Agency. New Frontiers of Knowledge, iv. 
age made clear that, "the regime of force and bad faith" was the final obstruction to recognizing the "indivisible oneness" of humankind. There was a widespread sense of what Jules Romains called "the common future of humanity" and the Brazilian anthropologist Gilberto Freyre called a technology-driven "pan-human conscience". ${ }^{56}$

Scientific and technological advances had made possible this vision of a unified human race. Often this unity was derived from the global threat that nuclear war presented. In general the speakers agreed that scientists were not a danger to humanity, or an obstacle to a peaceful global civilization, politicians were. Gilberto Freyre blamed "national leaders" for standing in the way of a "transnational and pan-human, though not uniform, social system." Since, as Charles Malik argued, scientists had "magnificently lived up to their promise"; now leaders must rise to the challenge. The world's political, intellectual and spiritual leaders were actually 'followers' when considered in relation to scientific community. To Malik, "The basic problem is political, intellectual and spiritual." Science was thus portrayed as a positive force, not only separate from politics but above politics. Setting science apart from politics and giving it a leadership role, suggested that the current ills of the world--the threat of nuclear annihilation chief among these--were the fault of social leaders and not of scientists. Any negative product of science was due to human mismanagement of the neutral resources of scientific knowledge and technological capabilities. As John

56 United States Information Agency. New Frontiers of Knowledge, 7, 27, 35, 43. 
von Neumann simply put it: "Technologies are always beneficial, directly or indirectly." 57

Of course all political leaders were not to blame. There were a variety of ways to govern a scientific society, and some would inevitably be better than others. As Arnold Toynbee observed in his lecture, technology can increase the threat of totalitarianism, by furthering the scope and power of methods of social control. Toynbee and the others held up American style democracy as the best type of political organization for a scientific society. This notion tied together all of the other significant themes, and most clearly laid bare the series' anti-Communist motivations. ${ }^{58}$

One final significant theme, stressing the revolutionary aspects of science and technology, further reflects this. As Percy Bridgman said in his lecture "The daily life of every inhabitant of this globe is in a process of drastic transformation." Science and technology, he believed, transform, "our complete world outlook". The transformative capacity of science and technology is emphasized throughout the series. Indeed, the original invitation to the symposium's participants, given by then Director of the USIA Theodore C. Streibert, conveyed a similar idea in its description of, "humanity [...] on the threshold of a new age". To Streibert, the revolutionary science of the atomic age was "but the scientific manifestation of an era of social, political and spiritual change." 59 Thus the "new frontier" was not a limited

57 Ibid., 4, 6, 36-37.

58 United States Information Agency. New Frontiers of Knowledge, 22-24.

59 Ibid., v, 12-13. 
description of possible scientific or technological breakthroughs, but reflected the perceived potential for breakthroughs in other spheres of human activity. By emphasizing first the positive aspects of science and technology, and then the notion that a scientific society would be a fundamentally reorganized society, the series encouraged its target audience to discard traditional norms and institutions in preparation for the foreseen--and welcome--"scientific" revolution. The strong antiCommunist direction of the series, however, suggested that the new frontier would bring a revolution more political than scientific.

\section{Concluding remarks}

Any examination of international communication during the period has to be seen in the context of the Cold War struggle for political, technological, and ideological supremacy between the western powers and the Soviet Bloc. This was even true of scientific information, even though many scientists at the time held that science was above politics. Throughout the 1950s, the relative level of scientific advancement became an increasingly crucial indicator of supremacy in the competitive posturing of the eastern and western superpowers. Especially during the International Geophysical Year, and in response to dramatic scientific breakthroughs such as the October 1957 launch of the first Sputnik, science moved to center stage in the arena of international propaganda. 
Nowhere was this truer than in American radio propaganda of the period. The New Frontiers of Knowledge series--and in 1960, the longer Forum Series--made the Voice of America the premier American outlet for disseminating abroad the views of distinguished scientists, scholars, and public figures. In 1968 George V. Allen looked back on his more than a decade of senior-level involvement with American international information programs and concluded that the USIA's most successful programs had been those that exercised the evolutionary as opposed to revolutionary approach, as did the New Frontiers of Knowledge series. ${ }^{60}$ It is clear that the series' emphasis on science played a very major role in this new approach to American propaganda in the 1950s, and that this propaganda depiction of American science complemented the broader foreign policy objectives of the United States.

To summarize the main themes of the New Frontiers of Knowledge series, it is helpful to restate Henry Luce's list of five ideals that Americans allegedly wanted: freedom to worship, peace, freedom to seek "scientific truth", prosperity, and democracy. The twin themes of peace and prosperity promoted the adoption of a scientific and technological society by attempting to persuade the audience that such a society is preferable to war and poverty. The series repeatedly stressed that the United States was the scientific society par excellence, presenting it as the protector of peace and prosperity. The American

60 George V. Allen, "USIA: The Big Problem is Belief," New York Herald Tribune, August 4, 1963; Ronald I. Rubin, The Objectives of the U.S. Information Agency, 111. 
way of life--and the social, intellectual and political traditions that this implied--was portrayed as the greatest insurance against global war and perpetual poverty. Emphasis on the transformative power of science and technology prepared the targeted audience for the political revolution, which would inevitably accompany the transition to a more technologically based society.

There was a wide range of topics dealt with in the Frontiers of Knowledge series, although none were treated in depth because of the short format of each contribution. The limitations to this breadth are revealing. For instance, Arnold Toynbee's suggestion that science and technology will increase the threat of totalitarian forms of government may at first seem diametrically opposed to the other speaker's assertions that technology and science are ultimately beneficial and lead to peace, prosperity, and democracy. It is arguable, however, whether Toynbee really offers a negative of view of science, or whether he simply provides a framework within which to assess the merits of different political approaches to creating a scientific society. Interpreting his and other's comments in the context of the Voice of America and the highly ambitious project to affect the hearts and minds of Soviet citizens, they take on a different shade of meaning. Almost all of the speakers agree that science is beneficial and they encourage the practice of science, and the appreciation of scientists. They stress that science has--and will continue to--transform societies. Most express the firm conviction that science improves society, and many explicitly make the connection between a scientific society and a democratic, 
free-market society. Toynbee simply recognizes that this is not an inevitable outcome but by no means is he unclear about which political and social forms he finds most preferable.

Clearly there is great tension in the intersection between the professed neutrality of science and the political rhetoric of propaganda. Scientific themes achieved a certain prominence in the highly politicized discourse of American propaganda during the late 1950s. Equating Western advances in the scientific and technological realm with Western social and political traditions, the New Frontiers of Knowledge series used a pointed portrayal of American scientific and technological development to promote the perception of American scientific, technical, and political supremacy. 


\section{Bibliography}

Allen, George V. "The People-to-People Program." Vital Speeches of the Day 24.10 (3 January 1958)

Alpert, Harry. "Public Opinion Research as Science." The Public Opinion Quarterly 20.3 (Fall 1956)

Bernhard, Nancy. U.S. Television News and Cold War Propaganda, 1947-1960. New York: Cambridge University Press, 1999.

Bogart, Leo. "A Study of the Operating Assumptions of the U.S. Information Agency." The Public Opinion Quarterly 19.4 (Winter 1955-1956)

Doherty, Thomas P. Cold War, Cool Medium: Television, McCarthyism, and American Culture. New York: Columbia University Press, 2003.

Elder, Robert E. The Information Machine: The United States Information Agency and American Foreign Policy. Syracuse: Syracuse University Press, 1968.

Grose, Peter. Operation Rollback: America's Secret War behind the Iron Curtain. Boston: Houghton Mifflin Company, 2000.

Heil, Alan L., Jr. Voice of America: A History. New York: Columbia University Press, 2003. 
Hixson, L. Walter. Parting the Curtain: Propaganda, Culture and the Cold War. New York: St. Martin's Press, 1997.

King, Gene. "A New Kind of Diplomacy," The Quarterly of Film Radio and Television 10.1 (Autumn 1955).

Krugler, David F. The Voice of America and the Domestic

Propaganda Battles, 1945-53. Columbia, Missouri: University of Missouri Press, 2000.

Lasswell, Harold D. “The Impact of Public Opinion Research On Our Society." The Public Opinion Quarterly 21.1, Anniversary Issue Devoted to Twenty Years of Public Opinion Research (Spring 1957).

Lazarsfeld, Paul F. "Public Opinion and the Classical Tradition," The Public Opinion Quarterly 21.1, Anniversary Issue Devoted to Twenty Years of Public Opinion Research (Spring 1957).

Lewis, Peter. The Fifties. London: Heinemann, 1978.

Lucas, Scott. Freedom's War: The American Crusade Against the Soviet Union. Washington Square, NY: New York University Press, 1999.

Mitrovich, Gregory. Undermining the Kremlin: America's Strategy to Subvert the Soviet Bloc, 1947-1956. Ithaca: Cornell University Press, 2000. 
National Security Council, "Discussion at the 339th Meeting of the National Security Council, Thursday, October 10, 1957," 11 October 1957, NSC Series, Box 9, Eisenhower Papers, 1953-1961 (Ann Whitman File)., Dwight D. Eisenhower Library, Abilene, Kansas.

Nelson, Michael. War of the Black Heavens: The Battles of Western Broadcasting in the Cold War. Syracuse: Syracuse University Press, 1997.

"News Briefs: "Overseas library"." Science 131.3396 (29 January 1960)

Nichols, Walter. "Voice of America Forum Series." College Art Journal 19.3 (Spring 1960).

Osgood Kenneth A. Total Cold War: Eisenhower's Secret Propaganda Battles at Home and Abroad. Lawrence: University Press of Kansas, 2006.

Osgood, Kenneth A. "Hearts and Minds: The Unconventional Cold War." Journal of Cold War Studies 4.2 (Spring 2002)

Peruse, Roland I. "Psychological Warfare Reappraised." In A Psychological Warfare Casebook, ed. William E. Daugherty, 25-35. Baltimore: John Hopkins Press, 1958. 
Puddington, Arch. Broadcasting Freedom: The Cold War Triumph of Radio Free Europe and Radio Liberty. Lexington, KY: University Press of Kentucky, 2000.

Rubin, Ronald I. The Objectives of the U.S. Information Agency: Controversies and Analysis. New York: Praeger, 1968.

Saunders, Frances Stonor. The Cultural Cold War: The CIA and the World of Arts and Letters. New York: The New Press, 1999.

Scott, John. "Non-Governmental Agencies Engaged in Cold War Propaganda Operations," in William E. Daugherty (ed)., A Psychological Warfare Casebook, Baltimore: John Hopkins Press, 1958.

Shaw, Tony. "Martyrs, Miracles, and Martians: Religion and Cold War Cinematic 'Propaganda in the 1950s." Journal of Cold War Studies 4.2 (Spring 2002).

Smith, Bruce Lannes. "Trends in Research on International Communication and Opinion, 1945-55," The Public Opinion Quarterly 20.1, Special Issue on Studies in Political Communication (Spring 1956).

Sorenson, Thomas C. The Word War: The Story of American Propaganda. New York: Harper \& Row, 1968.

The Board of Directors of the American Association for the Advancement of Science. "Strengthening the Basis of 
National Security." Science, New Series 120.3128 (10 December 1954).

United States Information Agency. New Frontiers of Knowledge: A Symposium by Distinguished Writers, Notable Scholars \& Public Figures. Washington, D.C. Public Affairs Press, 1957.

United States educational, scientific, and cultural motion pictures and filmstrips: education section 1958, selected and available for use abroad. Washington: United States Information Agency, 1959.

United States Information Agency, Office of Research and Analysis, "Impact of U.S. and Soviet Space Programs on World Opinion," 7 July 1959, U.S. President's Committee on Information Activities Abroad (Sprague Committee) Records, 1959-1961, Box 6, A83-10, Dwight D. Eisenhower Library, Abilene, Kansas.

United States, National Security Council. "Status of National Security Programs on June 30, 1958: Top Secret, National Security Council Report, NSC 5819." Digital National Security Archive. 9 September 1958. Available at http://nsarchive.chadwyck.com.login.ezproxy.library.ualbe rta.ca/cgi-

Wilson, Elmo C. "World-Wide Development of Opinion Research," The Public Opinion Quarterly 21. 1 (Spring 1957). 